\title{
Response to my critics
}

\author{
Ellen Hertz
}

Anna Beckers and Ioannis Kampourakis have formulated sophisticated critiques of 'The Great Shell Game', and I have learned a great deal from this exchange. Some of their criticism can be answered by clarifying the terms of the debate, which I do briefly below. I wish, however, to maintain the general thrust of my argument, and even to double down. With my title, I make an analogy between CSR and the confidence trick played by street operators who move pennies quickly between plastic cups and ask the assembled crowd to bet on where they end up. This game depends on skill but also on fraud, the operator working with a shill to mislead the audience. I suggest that as academics we must make sure that our sophistication does not place us in the role of the shill-preventing the public from noticing that corporations pocket the pennies.

As I read Ioannis Kampourakis, his main critique is of my use of the term 'the public'. He is correct in saying that I do not give adequate attention to this problematic notion. My only attempt to signal its complexity comes in my last sentence: 'the public-however difficult it is to locate'. To clarify, I follow John Dewey (1927) in viewing the public not as a pre-existing institutional reality but as an ever-evolving collective dynamic that citizens can (and do) bring into being to solve problems through inquiry, debate and contestation. This seems to me to be fundamentally compatible with Kampourakis's claim that we need a 'mobile critical practice ... that aspires to a democratic political economy'.

Interestingly, one rarely finds references to the public in CSR discourse nor to the associated phenomena of contestation and negotiation. On the contrary, the rhetoric of corporate 'citizenship' involves 'engagement' with 'communities', in a win-win world in which everyone can be a good guy. This is a quintessential expression of what Laura Nader (1990) calls 'harmony ideology': an attempt by dominant social actors to silence democratic deliberation by denigrating conflict. In this neocolonial fantasy, there are no unions, no environmentalists, no churches and, most importantly, there is no state. There are only 'stakeholders', social actors who are defined by their attachment to, not critique of, 
the business at hand, and with whom well-meaning companies can sit down to address 'challenges'. Conveniently, the fact that they might be the source of the problems to which solutions must be found disappears from view.

With Anna Beckers, the misunderstandings are more difficult to clarify, but I think I have identified one large one: when we refer to CSR, we are not referring to the same thing. By CSR, I am referring to the discourses and practices of corporate self-governance that multinationals have put into circulation over the past forty years to address criticism from NGOs, unions, and environmentalists. If I am reading Beckers correctly, sometimes she uses CSR in similar ways, as when she writes: it is a response to political contestation by the society in which companies are operating.' At other times, however, Beckers refers to 'a political space that is created within CSR practices', folding 'civil society, political regulation, and strategic litigation' into her conception of CSR. She then concludes that CSR is a field of 'constant contestation'.

In my view, this formulation is misleading. Including regulation and strategic litigation within the field opened up by CSR conflates into one what John Ruggie (2020) distinguishes as three distinct governance systems: 'public', 'civil', and 'corporate'. CSR is not a field but an object of constant contestation by actors located outside its discursive and operational parameters. To the extent that transnational corporate self-governance serves a purpose, it is as part of a 'smart mix' (Ruggie 2020) of hard and soft governance regimes that prevents corporations from acting simultaneously as players and as umpires in the global economic game (see Hertz and Schulz 2020).

Beckers's formulation raises the risk of obfuscation that I point to in my article and seems to downplay the role of law itself. To get a sense of this, imagine if theft were handled as are pollution, labor abuses and forced displacement under the corporate self-governance regime. Citizens who refrained from stealing, or who benefited knowingly but indirectly, would be congratulated, while society would plead with those who continued to steal to be more 'responsible'. As New York Times editor Binyamin Appelbaum says in a recent opinion piece (2020): 'There is an air of desperation about the incessant efforts to address [socioeconomic] problems by jawboning corporations to be better citizens.'

I believe it is time to conclude, with Appelbaum, that the great experiment in government deregulation and corporate self-governance launched in the Reagan-Thatcher era has failed. The globalized economy that unregulated multinationals have created has channeled enormous wealth into the hands of the already wealthy and intensified 
social and environmental injustices the world over. Their efforts at being responsible have proven inadequate, and the public-however difficult it is to locate-must step in.

\section{References}

Appelbaum, B. (2020), '50 years of blaming Milton Friedman: Here's another idea', The New York Times, 18 September 2020. https://www.nytimes.com/2020/09/18/ opinion/milton-friedman-essay.html.

Dewey, J. (1927), The Public and Its Problems (New York: Holt Publishers).

Hertz, E. and Y. Schulz (2020), Entreprises et droits humains: les limites de la bonne volonté / Unternehmen und Menschenrechte: Die Grenzen des guten Willens [Corporations and Human Rights: The Limits of Good Intentions] (Zurich: Seismo Verlag).

Nader, L. (1990), Harmony Ideology: Justice and Control in a Zapotec Mountain Village (Stanford, CA: Stanford University Press).

Ruggie, J. G. (2020), 'The paradox of corporate globalization: Disembedding and reembedding governing norms'. M-RCBG Faculty Working Paper Series 2020-01. Harvard Kennedy School. Available at https://www.hks.harvard.edu/centers/ $\mathrm{mrcbg} /$ publications/fwp (accessed 5 October 2020). 